\title{
Electroantennographic Responses of Heterotermes tenuis (Isoptera: Rhinotermitidae) to Synthetic (3Z,6Z,8E)-Dodecatrien-1-ol
}

\author{
Luciane G. Batista-Pereira ${ }^{a}$, Márcio G. dos Santos $^{a}$, Arlene G. Corrêa ${ }^{*, a}$, João B. Fernandes ${ }^{a}$, \\ Célia R. R. C. Dietrich ${ }^{b}$, Dilmar A. Pereira ${ }^{b}$, Odair C. Bueno ${ }^{b}$ and Ana Maria Costa-Leonardo \\ ${ }^{a}$ Departamento de Química, Universidade Federal de São Carlos, 13565-905 São Carlos - SP, Brazil \\ ${ }^{b}$ Departamento de Biologia e Centro de Estudos de Insetos Sociais, Instituto de Biociências, Universidade Estadual \\ Paulista, 13506-900 Rio Claro - SP, Brazil
}

\begin{abstract}
O cupim subterrâneo Heterotermes tenuis (Isoptera: Rhinotermitidae) é uma importante praga na economia brasileira, causando danos em reflorestamentos de eucalipto e plantações de cana-deaçúcar. O $(3 Z, 6 Z, 8 E)$-dodecatrien-1-ol tem sido descrito como feromônio de trilha em várias espécies da família Rhinotermitidae. Este trabalho teve como objetivo sintetizar este trieno e determinar, através da eletroantenografia, a seletividade e sensibilidade dos receptores antenais de $H$. tenuis ao (3Z,6Z,8E)-dodecatrien-1-ol e ao seu respectivo extrato de glândula esternal.
\end{abstract}

The subterranean termite Heterotermes tenuis (Isoptera: Rhinotermitidae) is a pest of great importance for the Brazilian economy as it causes serious damages in commercial reforestations of Eucalyptus spp. and sugarcane cultures. (3Z,6Z,8E)-Dodecatrien-1-ol has been identified as a pheromone of some species of subterranean termites. The objective of this research was to synthesize $(3 Z, 6 Z, 8 E)$-dodecatrien-1-ol and determine by electroantennographic (EAG) bioassays the selectivity and sensitivity of $H$. tenius antennae to its whole worker extract and to the synthetic triene alcohol.

Keywords: Heterotermes tenuis, Rhinotermitidae, (3Z,6Z,8E)-dodecatrien-1-ol, electroantennography, subterranean termite

\section{Introduction}

The subterranean termite Heterotermes tenuis (Isoptera: Rhinotermitidae) is a pest of great importance for the Brazilian economy as it causes serious damages in commercial reforestations of Eucalyptus spp. and sugarcane cultures. Attacks to the trunks of eucalyptus results in loss of the wood's quality, and may even lead to death of the tree. In sugarcane cultures, $H$. tenuis constitutes one of the most frequent pests with a particularly wide distribution, causing damages up to $10 \mathrm{t} \mathrm{ha}^{-1} / \mathrm{year}^{1}$

An alternative for the control of this pest is the use of attractive baits in monitoring systems. This is generally performed by means of coil-corrugated cardboard, inside a plastic bottle. Insects use several signals for localization of the habitat and choice of the food. Studies had demonstrated that during foraging, termites use trailfollowing pheromones to mark a trail. Each individual deposits a small amount of pheromone from the sternal

* e-mail: agcorrea@power.ufscar.br gland onto the substrate, which facilitates the localization and the identification of the food source. ${ }^{2,3}$

To date, trail-following pheromones have been identified in workers of only few termite species. $(1 E, 5 E, 9 E)$-Neocembrene is present in the species Nasutitermes exitiosus ${ }^{4}$ and Trinervitermes betonnianus ${ }^{5}$ both from the Termitidae family. (3Z)-Dodecen-1-ol was found in Macrotermes annandale $i^{6}$ and $(3 Z, 6 Z)$ dodecadien-1-ol in other fungus-growing termites. ${ }^{7}$ (3Z,6Z,8E)-Dodecatrien-1-ol (1) has been identified as the major component of the trail-following pheromone in the Rhinotermitidae family among the species Reticulitermes virginicus,,${ }^{8} R$. santonesis,,${ }^{9} 10 R$. lucifugus grassei, ${ }^{10} R$. speratus, ${ }^{11}$ and Coptotermes formosanus. ${ }^{12}$

$(3 Z, 6 Z, 8 E)$-Dodecatrien-1-ol is also the major component of the sex pheromone of some alates as Reticulitermes santonesis ${ }^{9}$ and $R$. lucifugus grassei. ${ }^{11}$ In addition, this compound was also found in sternal glands of Pseudacanthotermes spiniger female alates ${ }^{13}$ and in the tergal glands of Cornitermes bequaerti female alates, ${ }^{7}$ both Termitidae. 
Few syntheses of $(3 Z, 6 Z, 8 E)$-dodecatrien-1-ol have been described in the literature. ${ }^{14-16}$ Argenti et al. have employed a highly stereoselective convergent synthesis starting from 1-pentene and 3-butyn-1-ol which furnished $Z, Z, E-1$ in 10 steps and up to $6 \%$ overall yield. ${ }^{17}$

For a better understanding of the interactions mediated by semiochemicals it is important to study the aspects involved in the olfactory perception of these volatile compounds through electroantennographic experiments (EAG). Up to now the use of this technique for $H$. tenuis antennae has not been published. Therefore, the objective of this work was to synthesize $(3 Z, 6 Z, 8 E)$-dodecatrien-1ol and to determine the selectivity and sensitivity of the $H$. tenius antennae to worker extract and to the synthetic triene alcohol by using electroantennographic (EAG) bioassays.

\section{Experimental}

Synthesis of (3Z,6Z,8E)-dodecatrien-1-ol (1)

Unless otherwise noted, all commercially available reagents were purchased from Aldrich Chemical Co. Reagents and solvents were purified when necessary according to the usual procedures described in the literature. The IR spectra refer to films and were measured on a Bomem M102 spectrometer. ${ }^{1} \mathrm{H}$ and ${ }^{13} \mathrm{C}$ NMR spectra were recorded on a Bruker ARX-200 (200 and 50 MHz respectively). Mass spectra were recorded on a Shimadzu GC/MS-QP5000. Analytical thin-layer chromatography was performed on a $0.25 \mu \mathrm{m}$ film of silica gel containing fluorescent indicator $\mathrm{UV}_{254}$ supported on an aluminum sheet (Sigma-Aldrich). Flash column chromatography was performed using silica gel (Kieselgel 60, 230-400 mesh, E. Merck). Gas chromatography was performed with a Shimadzu GC-17A equipped with a DB-5 column ( $30 \mathrm{~m} \times 0.25 \mathrm{~mm}$, i.d. $0.25 \mu \mathrm{m}$; J \& W Scientific) using $\mathrm{H}_{2}$ as carrier gas.

1-Heptyn-4-ol (2). n-Butyraldehyde ( $8.00 \mathrm{~g}, 111 \mathrm{mmol})$ was added to a solution of propargyl bromide $(80 \%, 20.0$ $\mathrm{g}, 166 \mathrm{mmol})$ and $\mathrm{Zn}(11.8 \mathrm{~g}, 182 \mathrm{mmol})$ in THF $(66 \mathrm{~mL})$. After $30 \mathrm{~min}$ an aqueous solution of $\mathrm{HCl}(5 \% \mathrm{v} / \mathrm{v}, 20 \mathrm{~mL})$ was added, and the organic layer was extracted with ethyl ether $(3 \times 50 \mathrm{~mL})$, then dried over sodium sulfate and concentrated. The crude product was purified by distillation at reduced pressure $\left(90{ }^{\circ} \mathrm{C} / 35 \mathrm{mmHg}\right)$ affording the desired product 2 in $65 \%$ yield $(8.0 \mathrm{~g})$. IR $v_{\max } / \mathrm{cm}^{-1}: 1047,2118,3308,3422$ (film). ${ }^{1} \mathrm{H}$ NMR (200 $\mathrm{MHz}, \mathrm{CDCl}_{3}$ ) $\delta 0.94$ (t, J 7.0 Hz, 3H), 1.79 (sext, J 7.0 Hz, $2 \mathrm{H}), 2.05(\mathrm{t}, J 2.6 \mathrm{~Hz}, 1 \mathrm{H}), 2.36(\mathrm{~m}, 2 \mathrm{H}), 2.42$ (dd, J 2.6; 5.9 $\mathrm{Hz}, 2 \mathrm{H}), 4.78$ (s, 1H), $4.82(\mathrm{~m}, 1 \mathrm{H}) .{ }^{13} \mathrm{C}$ NMR $(50 \mathrm{MHz}$, $\left.\mathrm{CDCl}_{3}\right) \delta 17.5,18.7,24.7,32.7,70.6,74.6,93.0$.
1-Heptyn-4-yl p-toluenesulfonate (3). Alcohol 2 (10.0 $\mathrm{g}, 89.3 \mathrm{mmol}$ ) was added to a solution of $p$-toluenesulfonyl chloride (18.7 g, $98.2 \mathrm{mmol})$ and DMAP $(1.0 \mathrm{~g}, 8.9 \mathrm{mmol})$ in pyridine $(54 \mathrm{~mL})$. After stirring for $16 \mathrm{~h}$ at $\mathrm{rt}$, ice was added followed by an aqueous solution of $\mathrm{HCl}(10 \% \mathrm{v} / \mathrm{v}$, $10 \mathrm{~mL})$. The organic layer was extract with ethyl ether ( $3 \mathrm{x}$ $20 \mathrm{~mL}$ ), dried over sodium sulfate, and concentrated. Tosylate 3 was obtained in 95\% yield (22.5 g) after purification by column chromatography on silica gel. IR $v_{\max } / \mathrm{cm}^{-1}: 1097,1176,1364,2116,3291$ (film). ${ }^{1} \mathrm{H}$ NMR $\left(200 \mathrm{MHz}, \mathrm{CDCl}_{3}\right) \delta 0.83$ (t, $\left.J 7.2 \mathrm{~Hz}, 3 \mathrm{H}\right), 1.28$ (sext, $J$ $7.1 \mathrm{~Hz}, 2 \mathrm{H}), 1.70(\mathrm{q}, J 7.1 \mathrm{~Hz}, 2 \mathrm{H}), 1.96(\mathrm{t}, J 2.7 \mathrm{~Hz}, 1 \mathrm{H})$, 2.44 (s, 3H), 2.53 (dd, J 5.9; $2.7 \mathrm{~Hz}, 2 \mathrm{H}$ ), 4.57 (quint, $J 5.9$ $\mathrm{Hz}, 1 \mathrm{H}), 7.34$ (d, J $8.0 \mathrm{~Hz}, 2 \mathrm{H}), 7.80$ (d, J $8.0 \mathrm{~Hz}, 2 \mathrm{H}) .{ }^{13} \mathrm{C}$ $\operatorname{NMR}\left(50 \mathrm{MHz}, \mathrm{CDCl}_{3}\right) \delta 13.5,17.9,24.6,24.7,35.4,71.2$, 78.6, 80.0, 127.8, 129.0, 134.0, 144.7.

3-Hepten-1-yne (4). Tosylate 3 (3.0 g, $11 \mathrm{mmol})$ in diglyme solution $(10 \mathrm{~mL})$ was added dropwise to a solution of $t$-BuOK $(1.9 \mathrm{~g}, 17 \mathrm{mmol})$ in diglyme $(10 \mathrm{~mL})$ at $50^{\circ} \mathrm{C}$. The desired product was distilled of the reaction under reduced pressure. Enyne 4 was obtained in $86 \%$ yield $(0.86$ $\mathrm{g}$ ) as a $2: 1$ mixture of $E / Z$ isomers. IR $v_{\max } / \mathrm{cm}^{-1}: 650,960$, 2252, 3028, 3308 (film). Z-isomer: ${ }^{1} \mathrm{H}$ NMR (200 MHz, $\left.\mathrm{CDCl}_{3}\right) \delta 0.93(\mathrm{t}, J 7.2 \mathrm{~Hz}, 3 \mathrm{H}), 1.44$ (sext, $J 7.3 \mathrm{~Hz}, 2 \mathrm{H}$ ), $2.31(\mathrm{dq}, J 7.3,1.3 \mathrm{~Hz}, 2 \mathrm{H}), 3.07$ (d, J $2.1 \mathrm{~Hz}, 1 \mathrm{H}), 5.48$ (m, $1 \mathrm{H}), 6.0$ (ddd, $J 11.0 ; 7.4 ; 1.0 \mathrm{~Hz}, 1 \mathrm{H}) .{ }^{13} \mathrm{C}$ NMR $(50 \mathrm{MHz}$, $\left.\mathrm{CDCl}_{3}\right) \delta 13.8,22.1,32.4,75.7,82.7,108.2,146.1$. $E$-isomer: ${ }^{1} \mathrm{H}$ NMR $\left(200 \mathrm{MHz}, \mathrm{CDCl}_{3}\right) \delta 0.93(\mathrm{t}, J 7.2 \mathrm{~Hz}, 3 \mathrm{H}), 1.42$ (sext, $J 7.3 \mathrm{~Hz}, 2 \mathrm{H}$ ), 2.09 (dq, $J 7.3 ; 1.3 \mathrm{~Hz}, 2 \mathrm{H}), 2.77$ (d, $J$ $2.0 \mathrm{~Hz}, 1 \mathrm{H}), 5.42(\mathrm{~m}, 1 \mathrm{H}), 6.24(\mathrm{dd}, J 16.0 ; 7.0 \mathrm{~Hz}, 1 \mathrm{H}) .{ }^{13} \mathrm{C}$ $\operatorname{NMR}\left(50 \mathrm{MHz}, \mathrm{CDCl}_{3}\right) \delta$ 13.7, 21.9, 35.3, 81.2, 81.3, 108.7, 146.8 .

1-(Tetrahydro-2-pyranyloxy)-3-butyn-1-ol (5). In a 250 $\mathrm{mL}$ flask equipped with a magnetic stir bar and rubber septum containing a solution of 3-butyn-1-ol (Aldrich, 97\%) (5.00 $\mathrm{g}, 71.4 \mathrm{mmol})$ and Amberlyst ${ }^{\circledR} 15(0.50 \mathrm{~g})$ in dry dichloromethane $(86 \mathrm{~mL})$ was added 3,4-dihydro- $2 \mathrm{H}$-pyran $(7.20$ $\mathrm{g}, 85.7 \mathrm{mmol}$ ). The reaction mixture was stirred for $2 \mathrm{~h}$ at $\mathrm{rt}$ and then filtered. The organic layer was washed with a saturated solution of sodium bicarbonate, dried over sodium sulfate and concentrated in vacuo. The residue was purified by distillation $\left(135{ }^{\circ} \mathrm{C}, 35 \mathrm{mmHg}\right)(10.8 \mathrm{~g}, 98.0 \%$ yield). IR $v_{\text {max }} / \mathrm{cm}^{-1}: 640,1129,1444,2124,2876,3294$ (film). ${ }^{1} \mathrm{H}$ NMR (200 MHz, $\left.\mathrm{CDCl}_{3}\right) \delta 1.49-1.64(\mathrm{~m}, 6 \mathrm{H}), 1.68-1.87$ $(\mathrm{m}, 1 \mathrm{H}), 1.98(\mathrm{t}, J 2.7 \mathrm{~Hz}, 1 \mathrm{H}), 2.50(\mathrm{dt}, J 2.9 ; 7.0 \mathrm{~Hz}, 1 \mathrm{H})$, 3.49-3.61 (m, 2H), 3.81-3.91 (m, 2H); 4.65 (dd, J3.1, $4.0 \mathrm{~Hz}$, 1H). ${ }^{13} \mathrm{C} \mathrm{NMR}\left(50 \mathrm{MHz}, \mathrm{CDCl}_{3}\right) \delta 19.3,19.9,25.4,30.5$, 62.1, 65.5, 69.1, 81.4, 98.7. MS $m / z$ (rel. int.): 153 (3.8), 115 (9.5), 99 (32.4), 85 (100), 67 (56.6), 53 (72.7).

5-(Tetrahydro-2-pyranyloxy)-pent-2-yn-1-ol (6). A solution of $n$-butyllithium $(1.8 \mathrm{~mol} / \mathrm{L}$ in hexane, $9.9 \mathrm{~mL})$ 
was added dropwise to a solution of the protected alkynol $5(2.5 \mathrm{~g}, 16 \mathrm{mmol})$ in $\mathrm{THF}(20 \mathrm{~mL})$ at $-70{ }^{\circ} \mathrm{C}$ and the mixture was stirred under inert atmosphere for $40 \mathrm{~min}$. Paraformaldehyde $(0.47 \mathrm{~g}, 16 \mathrm{mmol})$ was added in one portion, then the temperature was allowed to rise to rt within $3 \mathrm{~h}$. Subsequently, a mixture of ice-water $(20 \mathrm{~mL})$ was added, and the organic material was extracted with ethyl ether (3 $x 50 \mathrm{~mL}$ ). The organic layers were combined, washed with aqueous ammonium chloride ( $2 \times 50 \mathrm{~mL})$, dried over $\mathrm{NaSO}_{4}$, and concentrated under reduced pressure. The crude product was purified by chromatography in silica gel and the alcohol 6 was obtained in $74 \%$ yield $(2.2 \mathrm{~g})$. IR $v_{\max } /$ $\mathrm{cm}^{-1}$ : 812, 1019, 1438, 2235, 2942, 3434 (film). ${ }^{1} \mathrm{H}$ NMR $\left(200 \mathrm{MHz}, \mathrm{CDCl}_{3}\right) \delta 1.42-1.81(\mathrm{~m}, 6 \mathrm{H}), 2.52(\mathrm{~m}, 2 \mathrm{H}), 2.95$ (bs, 1H), 3.56 (m, 2H), 3.84 (m, 2H), 4.22 (bs, 2H), 4,65 (bs, $1 \mathrm{H}) ;{ }^{13} \mathrm{C} \mathrm{NMR}\left(50 \mathrm{MHz}, \mathrm{CDCl}_{3}\right) \delta 19.3,20.1,25.2,30.4$, $50.8,62.2,65.6,79.5,82.6,98.7$.

5-(Tetrahydro-2-pyranyloxy)-1-pent-2-ynyl p-toluenesulfonate (7). To a solution of $6(3.9 \mathrm{~g}, 21 \mathrm{mmol})$ and DMAP $(0.25 \mathrm{~g}, 2.1 \mathrm{mmol})$ in anhydrous dichloromethane $(63 \mathrm{~mL})$ was added pyridine ( $2.5 \mathrm{~g}, 32 \mathrm{mmol})$ and $p$-toluenesulfonyl chloride ( $4.4 \mathrm{~g}, 23 \mathrm{mmol})$. The mixture was maintained at $\mathrm{rt}$ for $8 \mathrm{~h}$. The reaction was quenched with ice-water $(30 \mathrm{~mL})$, and the aqueous layer was extracted with dichloromethane ( $3 \times 20 \mathrm{~mL}$ ). The combined organic layers were washed with $10 \%$ aqueous $\mathrm{CuSO}_{4}(3 \times 10 \mathrm{~mL})$, saturated $\mathrm{NaHCO}_{3}$ $(10 \mathrm{~mL})$, and brine $(10 \mathrm{~mL})$, then dried over anhydrous $\mathrm{Na}_{2} \mathrm{SO}_{4}$. Solvent removal was followed by column chromatography on silica gel, using hexane and ethyl acetate $8: 2$ as eluent. The desired product 7 was obtained in $65 \%$ yield (4.6 g). IR $v_{\text {max }} / \mathrm{cm}^{-1}: 1177,1368,2243$ (film). ${ }^{1} \mathrm{H}$ NMR (200 MHz, CDCl $) \delta 1.44-1.78(\mathrm{~m}, 6 \mathrm{H}), 2.45$ (s, 3H), 3.35-3.99 (m, 4H), 3.98 (tt, J 7.0, 2.2 Hz, 2H), 4.50-4.60 (m, $1 \mathrm{H}), 4.69$ (t, $J 2.2 \mathrm{~Hz}, 2 \mathrm{H}), 7.32$ (d, $J 8.6 \mathrm{~Hz}, 2 \mathrm{H}), 7.83$ (d, $J$ $8.6 \mathrm{~Hz}, 2 \mathrm{H}) .{ }^{13} \mathrm{C}$ NMR $\left(50 \mathrm{MHz}, \mathrm{CDCl}_{3}\right) \delta 19.8,20.4,22.3$, 25.5, 30.6, 58.7, 62.4, 67.2, 72.9, 87.4, 98.9, 128.3, 129.9, 133.4, 145.1.

1-(Tetrahydro-2-pyranyloxy)-8-dodecen-3,6-diyne (8). Anhydrous, finely ground $\mathrm{K}_{2} \mathrm{CO}_{3}(0.29 \mathrm{~g}, 2.1 \mathrm{mmol}), \mathrm{NaI}$ $(0.53 \mathrm{~g}, 3.5 \mathrm{mmol})$ and $\mathrm{CuI}(0.67 \mathrm{~g}, 3.5 \mathrm{mmol})$ were suspended in DMF $(5.0 \mathrm{~mL})$ with stirring. Then compound 7 (0.47 g, $1.4 \mathrm{mmol})$ and 3-hepten-1-yne (4) (0.33 g, 3.5 $\mathrm{mmol})$ were added under nitrogen. The resulting mixture was stirred for $16 \mathrm{~h}$ at $\mathrm{rt}$. A saturated aqueous solution of $\mathrm{NH}_{4} \mathrm{Cl}(15 \mathrm{~mL})$ was added, and the product was extracted with ethyl ether $(3 \times 10 \mathrm{~mL})$. The organic extract was dried over sodium sulfate and concentrated in vacuo. The residue was purified by column chromatography on silica gel, using hexane and ethyl acetate $(95: 5)$. Diyne 8 was obtained in $70 \%$ yield $(0.25 \mathrm{~g})$ as a $2: 1$ mixture of $E / Z$ isomers. $E$-isomer: IR $v_{\text {max }} / \mathrm{cm}^{-1}: 734,1043,1122,1617$,
2241, 2887, 2945, 3026 (film). ${ }^{~} \mathrm{H} \mathrm{NMR}\left(200 \mathrm{MHz}, \mathrm{CDCl}_{3}\right.$ ) $\delta 0,93$ (t, $J 7,3 \mathrm{~Hz}, 3 \mathrm{H}$ ), 1.40 (sext, $J 7.3 \mathrm{~Hz}, 2 \mathrm{H}$ ), 1,48-1,86 $(\mathrm{m}, 6 \mathrm{H}), 2.05(\mathrm{dq}, J 7.3,1.4 \mathrm{~Hz}, 2 \mathrm{H}), 2.45(\mathrm{tt}, J 7.2,2.3 \mathrm{~Hz}$, $2 \mathrm{H}), 3.24(\mathrm{q}, J 2.2 \mathrm{~Hz}, 2 \mathrm{H}), 3.48-3.91(\mathrm{~m}, 4 \mathrm{H}), 4.64(\mathrm{t}, J 3.3$ $\mathrm{Hz}, 1 \mathrm{H}), 5.40(\mathrm{~m}, 1 \mathrm{H}), 5.87(\mathrm{~m}, 1 \mathrm{H}) .{ }^{13} \mathrm{C}$ NMR $(50 \mathrm{MHz}$, $\left.\mathrm{CDCl}_{3}\right) \delta 10.3,13.5,19.6,20.1,21.9,25.3,30.5,32.1$, $34.9,62.2,65.7,74.9,77.6,87.7,98.7,109.3,144.4$. Eisomer: IR $v_{\max } / \mathrm{cm}^{-1}: 968,1043,1122,1617,2241,2887$, 2945, 3026 (film). ${ }^{1} \mathrm{H}$ NMR (200 MHz, $\left.\mathrm{CDCl}_{3}\right) \delta 0.93$ (t, $J$ $7.3 \mathrm{~Hz}, 3 \mathrm{H}$ ), 1.42 (sext, $J 7.4 \mathrm{~Hz}, 2 \mathrm{H}$ ), 1.50-1.86 (m, 6H), $2.26(\mathrm{dq}, J 7.4 ; 1.5 \mathrm{~Hz}, 2 \mathrm{H}), 2.49$ (tt, $J 7.2 ; 2.3 \mathrm{~Hz}, 2 \mathrm{H}), 3.29$ (q, J $2.1 \mathrm{~Hz}, 2 \mathrm{H}), 3.48-3.91(\mathrm{~m}, 4 \mathrm{H}), 4.64(\mathrm{t}, J 3.3 \mathrm{~Hz}, 1 \mathrm{H})$, $5.45(\mathrm{~m}, 1 \mathrm{H}), 6.10(\mathrm{dt}, J 16.0 ; 7.0 \mathrm{~Hz}, 1 \mathrm{H}) .{ }^{13} \mathrm{C}$ NMR $(50$ $\left.\mathrm{MHz}, \mathrm{CDCl}_{3}\right) \delta 10.3,13.5,19.3,20.1,25.2,30.5,32.1$, 34.9, 62.0, 65.6, 75.1, 77.5, 77.5, 79.4, 98.6, 109.3, 144.4.

Dodecen-3,6-diyn-1-ol (9). To a solution containing diyne $8(0.28 \mathrm{~g}, 1.1 \mathrm{mmol})$ in methanol $(10 \mathrm{~mL})$ was added Amberlyst $^{\circledR} 15(0.028 \mathrm{~g})$, and the resulting mixture was stirred at $60{ }^{\circ} \mathrm{C}$ for $2.5 \mathrm{~h}$. Then a saturated solution of $\mathrm{NaHCO}_{3}(5 \mathrm{~mL})$ was added, and the organic layer was extracted with ethyl ether $(3 \times 10 \mathrm{~mL})$. The organic extract was dried over sodium sulfate and concentrated in vacuo. Alcohol 9 was obtained in $89 \%$ yield $(0.17 \mathrm{~g})$. Z $Z$-isomer: ${ }^{1} \mathrm{H}$ NMR $\left(200 \mathrm{MHz}, \mathrm{CDCl}_{3}\right) \delta 0.93(\mathrm{t}, J 7.3 \mathrm{~Hz}, 3 \mathrm{H}), 1.43$ (sext, J 7.3 Hz, 2H), 1.65-1.85 (m, 1H), 2.26 (dq, J 7.3, 1.4 $\mathrm{Hz}, 2 \mathrm{H}), 2.47$ (tt, J 7.2; $2.3 \mathrm{~Hz}, 2 \mathrm{H}), 3.30$ (q, J $2.2 \mathrm{~Hz}, 2 \mathrm{H}$ ), $3.71(\mathrm{t}, J 3.3 \mathrm{~Hz}, 2 \mathrm{H}), 5.45(\mathrm{~m}, 1 \mathrm{H}), 5.87(\mathrm{dt}, J 10.7 ; 7.4 \mathrm{~Hz}$, $1 \mathrm{H}) .{ }^{13} \mathrm{C} \mathrm{NMR}\left(50 \mathrm{MHz}, \mathrm{CDCl}_{3}\right) \delta 10.5,13.6,22.2,23.0$, 32.3, 62.2, 76.2, 77.5, 78.4, 87.9, 108.7, 143.9. E-isomer: ${ }^{1} \mathrm{H}$ NMR $\left(200 \mathrm{MHz}, \mathrm{CDCl}_{3}\right) \delta 0.89(\mathrm{t}, J 7.4 \mathrm{~Hz}, 3 \mathrm{H}), 1.39$ (sext, J 7.4 Hz, 2H), 1.65-1.85 (m, 1H), 2.06 (dq, J 7.4; 1.5 $\mathrm{Hz}, 2 \mathrm{H}), 2.49$ (tt, J 7.2; $2.3 \mathrm{~Hz}, 2 \mathrm{H}), 3.25(\mathrm{q}, J 2.1 \mathrm{~Hz}, 2 \mathrm{H})$, $4.64(\mathrm{t}, J 3.3 \mathrm{~Hz}, 2 \mathrm{H}), 5.42$ (m, 1H), 6.10 (dt, J 16.0; $7.0 \mathrm{~Hz}$, 1H). ${ }^{13} \mathrm{C} \mathrm{NMR}\left(50 \mathrm{MHz}, \mathrm{CDCl}_{3}\right) \delta 10.3,13.5,21.7,22.8$, 35.0, 61.2, 76.1, 77.1, 79.4, 81.8, 109.2, 144.7 .

(3Z,6Z,8E)-dodecatrien-1-ol (1). To a solution of alcohol $9(0.18 \mathrm{~g}, 1.0 \mathrm{mmol})$ in methanol $(10 \mathrm{~mL})$ was added quinoline $(0.5 \mathrm{~mL})$ and Lindlar reagent $(0.060 \mathrm{~g})$ and the resulting suspension was hydrogenated at room temperature for $6 \mathrm{~h}$. The mixture was filtered through Celite ${ }^{\circledR}$, washed with ethyl ether $(3 \times 10 \mathrm{~mL})$ and the filtrate evaporated at reduced pressure. Separation of the ZIE isomers through flash chromatography in silica gel using hexane : ethyl acetate $(8: 2)$ as eluent furnished Z,Z,E-1 $(0.108 \mathrm{~g})$ in $70 \%$ yield. MS $m / z$ 180, 133, 119, 105, 91, 79, 67, 55. The spectra data were identical with those reported in the literature. ${ }^{18}$

\section{Collection of the insects}

H. tenuis workers were collected in the agricultural zone of Indiaporã (195 58' 37"S 50 17' 19"W) - SP, Brazil, 
from January to February 2000. The collection was carried out with cylindrical corrugated cardboard baits $(10 \mathrm{~cm}$ diam, $15 \mathrm{~cm}$ height) placed underground at a depth of 20 $\mathrm{cm}$, close to poles infested with this termite species.

\section{Worker extract}

The extracted of 1500 workers of $H$. tenuis was prepared using methanol $(600 \mathrm{~mL})$ in a Soxhlet apparatus for $24 \mathrm{hr}$. Subsequently, the extract was divided in two parts. An aqueous solution of $\mathrm{KOH}(2 \% \mathrm{~m} / \mathrm{v})$ was added to one part and $2 \%(\mathrm{v} / \mathrm{v})$ distilled water was added to the other as a control. After $8 \mathrm{~h}$ at room temperature, the methanolic samples were extracted with purified hexane $(3 \times 10 \mathrm{~mL})$. The extracts were pooled, concentrated, and tested for activity in EAG bioassays. ${ }^{10}$

\section{Chemical analysis of natural extracts}

The extracts were analyzed by gas chromatography in a Shimadzu 17-A chromatograph equipped with DB-1 column (30 m x $0.25 \mathrm{~mm}$ i.d. $0.25 \mu \mathrm{m}$ film thickness; J \& W Scientific) coupled to a Shimadzu QP 5000 mass spectrometer, using helium as carrier gas. Injections of 1 $\mathrm{mL}$ of splitless gland extracts were made at $250{ }^{\circ} \mathrm{C}$. The initial oven temperature of $60^{\circ} \mathrm{C}$ was kept for $1 \mathrm{~min}$ and then increased to $240{ }^{\circ} \mathrm{C}$ at a rate of $2{ }^{\circ} \mathrm{C} / \mathrm{min}$, and finally to $280{ }^{\circ} \mathrm{C}$ at a rate of $5{ }^{\circ} \mathrm{C} / \mathrm{min}$. The final temperature was retained for $10 \mathrm{~min}$. Electron impact mass spectra $(70 \mathrm{eV})$ were obtained in the $m / z$ range of 33-250.

\section{Electroantennographic (EAG) bioassays}

H. tenuis antenna was excised (pulled out of the head) by means of a forceps and a few segments were cut off at the base and the tip. ${ }^{18}$ The antenna was then fixed between two stainless steel electrodes by placing the base and tip into droplets of an electrically conductive gel (Spectra $360^{\circledR}$ electrode gel) applied onto the metal electrodes. The specimen with the antennal preparation was placed in such a way that humidified air carried directed the compounds eluting from the stimulus delivery directly over the antenna. The antennal responses were amplified and recorded with a data acquisition controller and software EAG from Syntech.

The EAG response was evaluated in the following way: the compounds were released from Pasteur pipettes containing a piece of filter paper (c.a. $0.8 \mathrm{~cm}^{2}$ ), impregnated with $10 \mu \mathrm{L}$ of each prepared solution of the test compounds and passed over the antennae. In addition to the pipettes with the test preparations, one Pasteur pipette containing a filter paper impregnated with $10 \mu \mathrm{L}$ of the hexane solvent was used as control. The puff containing the test substance was delivered into a continuously humidified and purified air stream of $1.2 \mathrm{~L} \mathrm{~min}^{-1}$ by purified air, passing for 0.3 seconds through the impregnated filter paper in the pipettes. Hexane, air and filter paper $\left(0.8 \mathrm{~cm}^{2}\right)$ were used as control. Hexane stimulation was performed at the beginning and at the end of every series of EAG experiments. The test compounds were then applied randomly at intervals of 30 seconds. The EAG amplitudes in response to the synthetic compounds were expressed in relation to the responses to the control (hexane), because of the large differences in the overall sensitivities between individual antennae, and to compensate the decline in antennal sensitivity during a measuring session. In this normalization procedure the responses to the control were defined as $100 \%$. The values obtained between two references (hexane) were corrected according to the values of the references by linear interpolation. The Syntech EAG software calculated the normalized values automatically. The compounds were tested using 20 antennae of $H$. tenuis workers. The mean normalized responses of the different compounds were submitted to ANOVA for statistical analysis and compared using the Tukey test $(\mathrm{P}<0.05)$.

\section{Results and Discussion}

We have prepared $(3 Z, 6 Z, 8 E)$-dodecatrien-1-ol (1) through a convergent and stereoselective synthetic route adapted from the methodology described by Argenti et al. ${ }^{17}$ (Scheme 1). Thus, propargyl bromide was converted to 1-heptyn-4-ol (2), ${ }^{20}$ which was converted to the corresponding tosylate 3. Elimination of the tosyl group with $t$-BuOK furnished 3-hepten-1-yne (4) as an E/Z mixture in a 2:1 ratio. 3-Butyn-1-ol was protected and then treated with $n$-BuLi followed by paraformaldehyde to afford alcohol 6. This alcohol was converted to the corresponding tosylate $\mathbf{7},{ }^{21}$ which reacted with enyne $\mathbf{4}$ to furnish $\mathbf{8}$. Cleavage of the THP ether of $\mathbf{8}$ followed by Lindlar hydrogenation $^{22}$ of alcohol 9 and separation of the $Z / E$ isomers through flash chromatography furnished $Z, Z, E-\mathbf{1}$ in 9 steps and $23 \%$ overall yield.

Figure 1 shows the mean depolarization obtained by antennae of $H$. tenuis workers in response to the whole worker extract and to $(3 Z, 6 Z, 8 E)$-dodecatrien-1-ol (1). It was verified that both stimulations elicited antennal response significantly higher than response for the control (hexane). The worker extract presented statistical difference when compared with $Z, Z, E-\mathbf{1}$. These results indicate that workers of $H$. tenuis recognize the volatile present in the worker extract and also $Z, Z, E-\mathbf{1}$, though it has not yet been found in the worker extract by GC-MS analysis. 


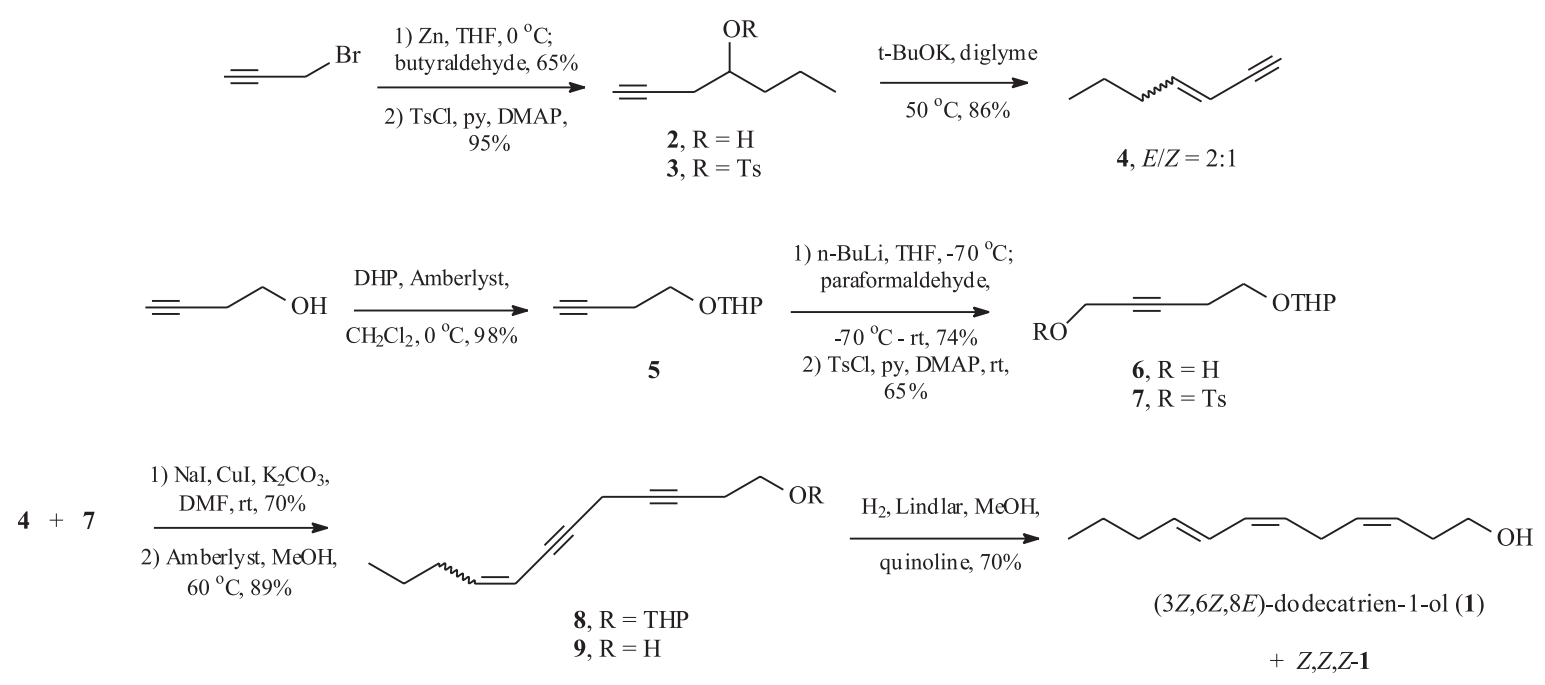

Scheme 1. Synthesis of $(3 Z, 6 Z, 8 E)$-dodecatrien-1-ol (1).

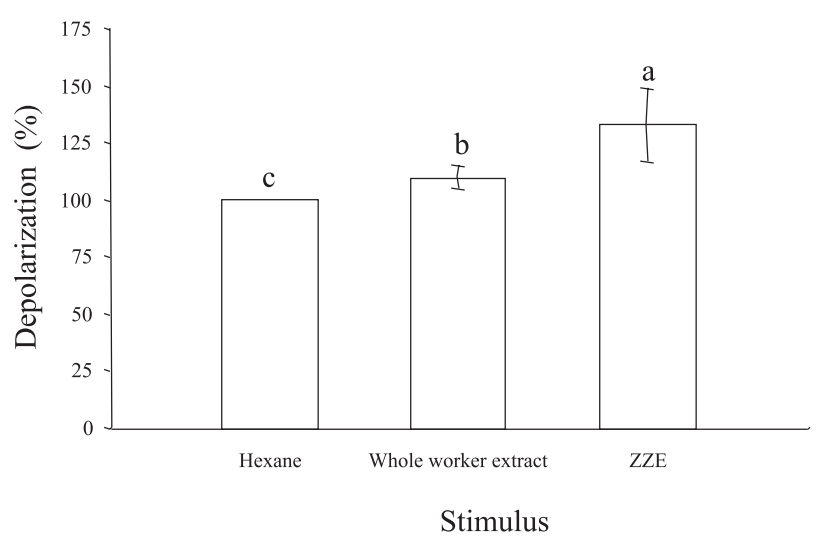

Figure 1. Electroantennographic (EAG) response $(\mathrm{mV})$ of $H$. tenuis workers to different stimuli: hexane, whole worker extract of $H$. tenuis and $(3 Z, 6 Z, 8 E)$-dodecatrien-1-ol $(\mathrm{N}=20$ antennae). The stimuli were delivered from impregnated filter paper by using a continuously humidified and purified air stream of $1.2 \mathrm{~L} \mathrm{~min}{ }^{-1}$. Means followed by the same letters are not different by Tukey test $(\mathrm{P}=0.05)$.

In Figure 2 it is verified that the binary mixture containing Z,Z,E- and Z,Z,Z-1 (1: 1) showed the highest depolarization in $H$. tenuis antennae, followed by pure $Z, Z, E-1$, which showed an intermediate activity and its stereoisomer $Z, Z, Z-1$. These compounds elicited a statistically different response as compared to the hexane, air, and paper (cellulose) controls. The stimulation by air (mechanical) caused lower depolarization in the H. tenuis antenna.

To the best of our knowledge, this is the first time that EAG experiments with termite antennae using a synthetic compound have been reported. EAG experiments with $H$. tenuis antennae were effective because the depolarization of the antenna for different stimulation and the response was selective. Our investigations demonstrate that the

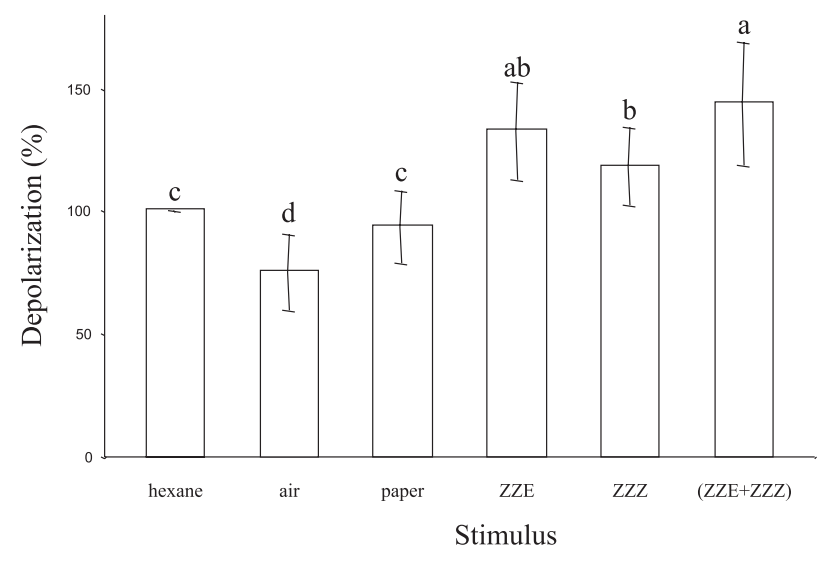

Figure 2. Electroantennographic (EAG) response $(\mathrm{mV})$ of $H$. tenuis workers to different stimuli: hexane, air, paper (cellulose), (3Z,6Z,8E)-dodecatrien-1-ol (1), (3Z,6Z,8Z)-dodecatrien-1-ol and a mixture of $Z, Z, E$ - and $Z, Z, Z-1(1: 1)(\mathrm{N}=20$ antennae). The stimuli were delivered from impregnated filter paper by using a continuously humidified and purified air stream of $1.2 \mathrm{~L} \mathrm{~min} \mathrm{~m}^{-1}$. Means followed by the same letters are not different by Tukey test $(\mathrm{P}=0.05)$.

antennae of $H$. tenuis possess chemoreceptors for $Z, Z, E-1$ and $Z, Z, Z-1$. These results may indicate $Z, Z, E-\mathbf{1}$ to play a role in the biology of $H$. tenuis, i.e, as a signal in chemical communication.

$(3 Z, 6 Z, 8 E)$-Dodecatrien-1-ol has been identified as component of the trail-following pheromone in several species of the Rhinotermitidae. Heterogeneric isolations suggest that this alcohol may be a trail pheromone common to the family Rhinotermitidae. ${ }^{18}$ Thus, a question is raised concerning the specificity of termite pheromones and the mechanism of colony isolation. Wobst et al. mention that 
in some cases the choice of trails could be easily explained by quantitative differences of secreted pheromone. ${ }^{10}$ Other data suggest that trail pheromones probably are multicomponent systems. Wobst et al. also state that in termite species in which the workers do not forage the nest, secretions of their external gland probably allow them to mark and recognize their environment and to coordinate their activities of excavating. In species that forage outside the nest, termites very often move along subterranean tunnels or galleries on the surface which may be considered as expansions of the nest and serve as physical guides. In this case, the orientation role of the trail-following pheromone is limited to the first steps in building the galleries. H. tenuis presents the profile of this group. In fact, specific trails only appear useful for termite species foraging above ground in open air and far from the nest.

In order to contribute to the understanding of the role of $(3 Z, 6 Z, 8 E)$-dodecatrien-1-ol in the behavior of this species, biological studies are in progress and will be published elsewhere in due course.

\section{Acknowledgements}

The authors thank Elektro Eletricidades e Serviços S.A., CNPq, FAPESP (Brazil) and IFS (Sweden) for financial support.

\section{References}

1. Arrigoni, E. B.; Almeida, L. C.; Kasten Jr.; P. Precetti, A.A.C.M.; Bol. Tec. Copersucar 1989, 48, 38.

2. Almeida, J. E. M.; Alves, S. B.; An. Soc. Entomol. Brasil 1995, 24, 619 .

3. Costa-Leonardo, A. M.; Cupins-Praga: Morfologia, Biologia e Controle, Divisa: Rio Claro, 2002.

4. Birch, A. J.; Brown, W. V.; Corrie, J. E. T.; Moore, B. P.; J. Chem. Soc. 1972, 2653.

5. McDowell, P. G.; Oloo, G. W.; J. Chem Ecol. 1984, 10, 835.

6. Peppuy, A.; Robert, A. ; Sémon, E. ; Giniès, C. ; Lettere, M. ; Bonnard, O. ; Bordereau, C.; J. Insect. Physiol. 2001, 47, 445 .
7. Bordereau, C.; Cancello, E. M.; Sémon, E.; Courrent A.; Quennedey, B.; Insectes Soc. 2002, 49, 209.

8. Matsumura, F.; Coppel, H.C.; Tai, A.; Nature 1968, 219, 963.

9. Laduguie, N.; Robert, A.; Bonnard, O.; Vieau, F.; Le Quéré, J. L.; Sémon, E.; Bordereau, C.; J. Insect Physiol. 1994, 40, 781.

10. Wobst, B.; Farine, J.P.; Ginies, E. S.; Sémon, E.; Robert, A.; Bonnard, O.; Connétable, S.; Bordereau, C.; J. Chem. Ecol. 1999, 25, 1305.

11. Yamaoka, R.; Tokoro, M.; Hayashiya, K.; J. Chromatogr. 1987, 399, 259.

12. Tokoro, M.; Tsunoda, K.; Yamaoka, R.; Wood Res. 1989, 76, 29.

13. Bordereau, C.; Robert, A.; Bonnard O.; Le Quéré, J. L.; J. Chem. Ecol. 1991, 17, 2177.

14. Ikeda, Y.; Ukai, J.; Ikeda, N.; Yamamoto, H.; Tetrahedron Lett. 1984, 25, 5177.

15. Ikeda, Y.; Ukai, J.; Ikeda, N.; Yamamoto, H.; Tetrahedron 1987, 43, 743.

16. Eya, B.K.; Otsuka, T.; Kubo, I.; Wood, D. L.; Tetrahedron 1990, 46, 2695.

17. Argenti, L.; Bellina, F.; Carpita, A.; Rossi, E.; Rossi, R.; Synth. Commun. 1994, 24, 2281.

18. Tokoro, M.; Takahashi, M.; Yamaoka, R.; Mokuzai Gakkaishi 1992, 38, 593.

19. Bjostad, L. B. In Methods in Chemical Ecology: Chemical Methods; Haynes K. F.; Millar, J. G., eds., Chapman and Hall: London, 1998, p. 339-369, vol. 1.

20. Whiting, M. C.; Eglinton, G.; J. Chem. Soc. 1950, 3650.

21. Ivanov, I.V.; Groza, N.V.; Romanov, S.G.; Kuhn, H.; Myagkova, G.; Tetrahedron 2000, 56, 553.

22. Rodriguez, A.; Nomen, M.; Spur, B.W., Godfroid, J. J.; Lee, T. H.; Tetrahedron 2001, 57, 25.

Received: September 3, 2003

Published on the web: May 10, 2004

FAPESP helped in meeting the publication costs of this article. 